p-ISSN: 2559-7639 | e-ISSN: 2668-0718 | DOI:10.18662/jsmi | Frequency | 1 issue per year

with 1-2 possible supplementary issues

Covered in I CrossRef; RePEC; CEEOL; Google Scholar, ICI Journals Master List - Index Copernicus

2020, Volume 2, Issue 1, pages: 100-1 14| DOI: https://doi.org/10.18662/jsmi/2.1/9

\section{The Necessary Conditions for the Implementation of Articial \\ Intelligence Ethics}

\section{[Condițiile necesare pentru implementarea unui sistem etic inteligențelor artificiale]}

\section{Cristian RADU ${ }^{1}$}

${ }^{1}$ Student, Faculty of History and Philosophy, Department of Philosophy, Babeş-Bolyai University, Cluj-Napoca, 1 Mihail Kogălniceanu Street, 400084, Romania. E-mail cristiradu1991@gmail.com.

\begin{abstract}
The implementation of artificial intelligence morality is one of the most important themes discussed in the field of A.I. While many discussions focus on finding the right ethical system to implement, it is also important to address an important dilemma that comes with this possible innovation. Besides finding the right ethical system for A.I, we must also be aware of the conditions required to make possible the implementation of such a system. And these are not hardware requirements, but specific traits through which A.I. become more akin to humans. In this article, I will discuss what features do a.i. need to have in order to work with abstract ideas such as morality. To do this, I will first write a definition of human nature, based on past definitions written by various philosophers. And starting from this definition, I will highlight the most fundamental and essential human traits such as thinking and the nature of buman rationality, communication, and the relationship between mind and body. After, I will compare these traits with a.i. to find out how close or far is the technology of achieving moral thinking. In order to accomplish these, I will use secondary sources of literature such as books and articles.
\end{abstract}

Keywords: artificial intelligence; morality; ethics; human; mind; body; communication;

How to cite: Radu, C. (2020). The Necessary Conditions for the Implementation of Articial Intelligence Ethics [Condițiile necesare pentru implementarea unui sistem etic inteligențelor artificiale]. Journal for Social Media Inquiry, 2(1), 100-114 https://doi.org/10.18662/jsmi/2.1/9 


\section{Introducere}

Posibilitatea implementării unui sistem de moralitate inteligențelor artificiale este una dintre cele mai discutate teme curente din domeniul tehnologiei. Majoritatea discuțiilor pe această temă se concentrează pe alegerea unui model etic eficient de implementat. Dar, posibilitatea unui astfel progres aduce cu ea o dilemă proprie. Mai exact, trebuie să stabilim care sunt condițiile necesare care fac posibilă implementarea unui sistem etic inteligențelor artificiale. Nu este vorba doar de latura hardware, ci este vorba de anumite trăsături prin care sistemul inteligenței artificiale devine asemeni omului, pentru a putea fi capabil de moralitate. În acest studiu, voi alcătui întâi o definiție al omului, pe baza mai multor teorii filosofice, care cuprinde trăsăturile sale esențiale. După care, cu ajutorul acestei definiții, voi face o comparație cu inteligențele artificiale pentru a evidenția care sunt trăsăturile necesare care fac posibilă implementarea unui sistem moral.

\section{Definiția omului}

Putem observa o parte din trăsăturile omului printr-o analiză a testului Turing. Numit după filosoful și matematicianul care 1-a conceput, Alan Turing, acest test a fost conceput pentru a evalua inteligența unei i.a. sau al unui robot.

Acest test ia forma unui interviu, în care i.a. și oamenii sunt evaluaţi de un juriu, format tot din oameni. Rolul participanților, umani și non umani, este de a convinge juriul de umanitatea lor. Dacă juriul nu poate deosebi i.a. de un om sau nu poate identifica care este i.a. dintre participanți, atunci aceștia pot considera că i.a. are o inteligenţă de nivel uman. Mai exact, prin inteligență înțelegem aici capacitatea de comunicare, inteligența emoțională și inteligența generală (Turing, 1950).

Trăsăturile necesare pentru ca i.a. să poată fi implementată cu un sistem etic se pot stabili pornind de la una din cele mai populare definiții ale acestea. Deși ea poate fi definită din mai multe puncte de vedere, o inteligența artificială, în multe instanțe, este definită ca o mașinărie, un computer sau un robot care mimează omul sau o cogniție umană (Russe, \& Norvig, 2009). Astfel, fiindcă moralitatea care se dorește a fi implementată este cea umană, trebuie să răspundem la următoarele întrebări: Cum poate fi o i.a. asemănătoare omului? Dacă i.a. imită omul, poate fi ea implementată cu un sistem etic? 
Pentru a putea compara i.a. artificială cu omul, trebuie să stabilim care sunt trăsăturile care intră în definiția omului și apoi dacă acestea sunt prezente în cazul inteligențelor artificiale.

O definiție, care să cuprindă ce este omul și ce este uman, este dificil de alcătuit. În funcție de caracteristicile lui, omul poate fi definit ori printr-o trăsătură esențială, necesară și universală, ori prin concepții care consideră că omul este indefinibil, pentru că nu ar avea o trăsătură esențială.

Începând în antichitate, prin Socrate, filosofia se concentrează pe om ca subiect filosofic. Potrivit acestuia, cel mai adecvat mod de a trăi și cel mai potrivit naturii omului este cel fundamentat pe rațiune. Această rațiune se bazează pe critică și cunoaștere adevărată. Forma ei este evidențiată prin metoda socratică, menționată prima oară în dialogul platonic Theaetetus. În cadrul textului, Socrate, asemeni unei moașe, prin întrebări și prin dialog, îl ghidează pe tânărul Theaetetus să gândească critic și să înţeleagă ce este cunoașterea (Platon, 2013).

Această formă a rațiunii este prezentă și în celelalte dialoguri platonice și are rolul de a cerceta și de a înțelege concepte etice precum justiția sau virtutea. Potrivit lui Gregory Vlastos, metoda socratică este o metodă de eliminare a ipotezelor, prin aceea că se găsesc ipoteze mai bune prin identificarea și eliminarea constantă a ipotezelor care duc la contradicții (Vlastos, 1983).

Mai departe, Platon, în Alcibiade, definește omul ca trup și suflet/rațiune. Sufletul/rațiunea, în această relaţie, este mai presus decât trupul, pentru că între cele două nu poate fi o simplă alăturare. Sufletul este determinat, definitoriu, fiind mai presus de individ și de specia umană (Platon, 1976). Sufletul este compus din mai multe părți: partea inferioară sau apetentă care cuprinde nevoile biologice, partea pasională, care cuprinde patimi, pasiuni și este superioară părții apetente, iar ultima, partea rațională (Platon, 1986). În concluzie, în viziunea platoniciană, rațiunea stă la baza sufletului și cuprinde toată experiența umană necesară, pentru ca omul să poată interacționa cu lumea prin intermediul trupului.

Aristotel dezvoltă mai departea importanța rațiunii, susținând că este nu numai cea mai importantă trăsătură, ci este scopul și menirea omului. Pe lângă importanța sufletului, Aristotel evidențiază noi trăsături în definiția omului. Potrivit lui, omul este o ființă socială care necesită companie, indiferent de contextul lui. Și nu este vorba de orice prietenie, ci una care este practică, permanentă şi plăcută de dragul ei. $\mathrm{O}$ astfel de relație, asigură prosperitatea și dezvoltarea virtuoasă a tuturor participanților ei (Aristotel, 2002). Totodată, omul, la maturitate, se cuplează cu un alt adult pentru o forma un cămin, un 
clan sau o comunitate (Aristotel, 2002, p.135). Această abilitate se poate dezvolta mai departe, producând structuri complexe precum orașele, organizarea muncii și a legii pe baza rațiunii (Aristotel, 1959). În final, o trăsătură esențială este imitația. Încă de mici, copii încep să înțeleagă cum funcționează lumea prin imitație. Interesul pentru imitație se menține și la maturitate pentru că omul simte o anumită plăcere când percepe o asemănare a unui lucru cu altul.Iar, din această percepție, el învață noi lucruri despre lume (Aristotel, 2006, pp. 10-11).

În Evul Mediu, elementul divin creștin joacă un rol important în relație cu natura umană. În viziunea Sf. Augustin, se menține distincția platonică dintre trup și suflet. Sufletul, de asemenea, este superior trupului, dar din motive ierarhice. Sufletul este substanța care există, trăiește, este strâns legat de rațiune și este cel capabil să domine trupul (Sf. Augustin, 2010). Dar, datorită naturii păcătoase a omului, echilibrul între cele două părți este destabilizat și este necesară intervenția lui Dumnezeu pentru salvare.

Mai departe, Toma D'Aquino susține importanța rațiunii, adăugând că omul este capabil de revelații divine prin intervenția lui Dumnezeu (D’Aquino, 1997). Tot legat de rațiune, aceasta este fondată pe baza legilor. Pornind de la legile naturii, omul își formează cunoștiințele despre lume și pe baza acestor cunoștințe își formează propriile legi. Pe lângă acestea, este necesară și legea divină provenită din textele sfinte (D’Aquino, 2014). Asemeni lui Aristotel, Thomas D'Aquino este de părere că natura omului implică căsătoria și formarea unei familii.

După Evul Mediu, în epoca Premodernă, René Descartes a definit omul ca o unitate dintre minte și trup. Potrivit lui Descartes, mintea poate supraviețui fără trup, dar trupul fără minte nu poate (Dicker, 2013). Mai mult, cele două se întrepătrund, formând o unitate. Altfel nu am putea fi în stare să simțim, ci am fi doar conștienți că ceva i se întâmplă trupului (Descartes, 2017, p. 56).

O descriere semnificativă a naturii umane a fost făcută de către filosofii contractualiști. Aceste definiții, au fost concepute din punctul de vedere a socialității umane. Mai concret, această trăsătură nu este una înnăscută pentru că umanitatea a trecut prin două etape, starea naturală și cea socială. Printre filosofii care descriu natura umană din această prismă, îi puten enumera pe Thomas Hobbes, John Locke și Jean Jacques Rousseau.

Toți filosofii din această categorie recunosc cele două stări și toți cred că, în starea naturală, omul este o ființă absolut liberă din punct de vedere social-politic, pentru că este o ființă solitară. Nu trăiește în comunități, ci trăiește izolat în natură, nu interacționează cu semeni săi și nu i se pot impune 
restricții, nu trebuie să ceară permisiuni, voința lui nu depinde de voința altora. Dar, la un moment dat, omul trece de la această stare la una socială. Trecerea şi cauzele trecerii diferă de la un gânditor la altul.

Conform lui Thomas Hobbes, natura omului este una agresivă, violentă și posedă un risc major de distrugere reciprocă. Acestă situație face necesară contractul social, în schimbul libertății. Însă nu toate libertăţiile pot fi pierdute, dreptul la viață, fericire, libertate și proprietate nu pot fi negociate (Hobbes, 1998).

Diferit faţă de Hobbes, John Locke susține că omul, în starea naturală, nu este nici bun, nici rău, nu are o natură prederminată cu care să vină în lume. Conform lui Locke, fiecare individ, în temeiul experienței sale, a cunoașterii senzoriale, își formează o anumită natură umană. Omul va renunța la starea naturală pentru că viața lui este periclitată de universul fizic și se va alătura altor semeni pentru a-și apăra libertatea proprie (Locke, 1996).

În final, Rousseau crede că omul este bun în starea naturală, dar este obligat să renunțe la această stare. Această trecere este cauzată atât de un determinism geografic cât și din motive subiective precum opțiunea pentru starea socială și sentimentul de iubire (Wraight, 2008, p. 57).

Rousseau, față de restul, a adus o contribuție semnificativă în ceea ce privește analiza stării naturale. Potrivit lui, rațiunea, limbajul și comunitățile au fost concepute accidental de om. Concluzia la care ajunge, este că natura omului nu este una fixă, iar tot ceea ce este acum, nu era în trecut (Rousseau, 1968). Acest fapt duce la realizarea că viața bazată doar pe raţiune nu este una fericită. Astfel, omul civilizat duce o viață dezechilibrată și nefericită pentru că viața lui este un amestec ineficient de civilizație și tendințe naturale, iar starea naturală este cea mai potrivită lui (Rousseau, 2012, p. 64).

Blaise Pascal, în definirea naturii umane, scoate în evidență paradoxurile ei. A conceput trei definiții ale naturii umane care corespund celor trei etape ale gândirii sale. Într-o primă instanță, acesta este un apologet al omului, văzând în el doar marile lui calități și refuzând să-i recunoască căderile. Apoi, în următoarea etapă, pune accent pe slăbiciunile omului (Clarke, 2007).

Omul este o ființă paradoxală și plină de contradicții. Din punct de vedere moral, este și cea mai măreață și cea mai josnică ființă. Este un depozitar al adevărului, dar adună totodată erori, cunoștiințe slabe și incomplete. Este o ființă măreață, dar este și cea mai fragilă, universul o poate anihila cu un minim de efort. Măreția lui este dată de rațiunea care-i permite să aibă conștiința propriei sale morți. Știe că va muri și are puterea să-și conștientizeze și să-și asume propria moarte, devenind o fință tragică. Din 
această perspectivă natura umană este una eroică pentru că, prin rațiune, știe că va muri și își asumă acest lucru. Intră în contact cu absolutul, cu limita, o conștientizează și o asumă (Pascal, 2013). În concluzie, conștiința morții înseamnă tragism, iar asumarea ei înseamnă eroism. În a treia fază, accentuează mai mult slăbiciunea ființei umane, spunând că omul trăiește între două infinituri: macrocosmosul și microcosmosul.

În epoca modernă, descrierile naturii umane s-au diversificat. Jean-Paul Sartre pornește de la premisa că natura omului nu este definibilă pentru că nu există o notă esențială, fundamentală și comună tuturor oamenilor (Flynn, 2004). El consideră că Dumnezeu nu există, astfel nu există un creator care să creeze o natură umană predeterminată. Comparat cu un animal, situația omului este inversă.

În cazul animalului, natura este predestinată, deci esența precede existența. În schimb, în cazul omului, existența precede esența. Întâi se naşte, există și doar după își alege esența. Oamenii, conform lui Sartre, dispun de o libertate și o responsabilitate, care se obiectivează sub forma alegerii. Există o alegere neîngrădită care-i permite omului să opteze pentru orice esență. Ceea ce nu se poate refuza este libertatea, fapt care nu este neapărat un dar, pentru că, atunci când un anumit om alege o anumită esență, el își pierde posibilitatea de a opta pentru o infinitate de alte esențe, ceea ce-1 transformă într-o ființă tragică. Mai mult, această libertate aduce implicit cu ea o responsabilitate, pentru că fiecare este responsabil pentru alegerea făcută (Sartre, 1978).

În final, Ernst Cassirer definește omul ca animal symbolicum. Susține că nu există o formulă unică și simplă a omului. Contradicția este singurul element caracteristic al omului, pentru că nu există o natură umană simplă și omogenă. Față de animale, care doar simt și reacționează, omul are un sistem în plus: sistemul simbolic (Friedman, 2004).

Această trăsătură unică îi marchează viața și îi permite să trăiască întro nouă dimensiune a realității. Există o diferență între dimensiunea organică imediată specifică animalelor și reacțiile umane care sunt întârziate datorită rațiunii. Iar, prin prezența culturii, este necesară extinderea definiției omului ca animal rațional la animal simbolic. Prin această definiție, se poate sesiza diferența specifică a omului pentru că proprietatea fundamentală a omului nu este nici fizică și nici metafizică. Astfel, nu este corect să reducem creația umană doar la una beletristică și științifică. Omul își pune întrebări despre sensul existenței sale, iar aceste întrebări vor primi un răspuns mulțumitor, dacă omul își înțelege existența (McLaughlin \& Lentricchia, 1990). 
Pe baza diferitelor definiții enumerate mai sus, putem realiza un model aproximativ pentru om, pentru a putea face o comparație cu inteligența artificială. Este, în primul rând, o ființă dominată de rațiune. Cu ajutorul ei, omul gândește critic și are posibilitatea de a ajunge la cunoașterea adevărată. Prin dezvoltarea rațiunii omul cunoaște lumea, își dezvoltă limbajul, istoria, cultura și își poate alege soarta și destinul. Inițial dominat de mediu, precum restul animalelor, omul, prin rațiune, s-a impus asupra naturii și și-a creat civilizaţia. Rațiunea, totodată, este legată de dualitatea suflet/minte și trup. Prin comunicare și cooperare, el socializează și împreună cu alți semeni formează structuri sociale precum familia, clanul sau comunitatea.

\section{Trăsăturile umane în relație cu i.a.}

\subsection{Rațiunea}

Prima trăsătură, pe baza căreia i.a. este comparată cu omul și care este fundamentală pentru orice sistem moral, este rațiunea. De la implementarea inteligențelor artificiale până în prezent, discuțiile legate despre natura cognitivă a inteligențelor artificiale s-au purtat din două puncte de vedere. Cei care susțin că i.a. au posibilitatea să ajungă la o rațiune de tip uman și cei care spun că niciodată nu vom putea avea i.a. care să gândească asemeni unui om. Dar, prin analiza acestor argumente, se poate observa, mai degrabă, o discuție despre felul în care fiecare înțelege ce este inteligența umană și secundar ce înseamnă inteligența în legătură cu i.a. O caracteristică a acestor argumente este că acestea par să pună accentul pe două aspecte. Unele analizează i.a. printr-o orientare a argumentelor spre o perspectivă interioară, analizând sistemul în sine, iar altele argumentează capacitatea cognitivă a i.a. printr-o analiza a acțiunilor întreprinse de acestea.

Din prima categorie fac parte argumentele filosofilor și a teologilor care susțin că inteligența artificială ar fi imposibilă, pentru că o mașinărie nu are un suflet, o conștiință, creativitate, înțelegere sau o altă trăsătură similară, tipic umană. Dar, după cum spune Stuart Armstrong, pentru acești gânditori este dificil să găsească acel "ceva" comun pentru a putea găsi un argument definitiv împotriva posiblităților cognitive ale inteligențelor artificiale" (Armstrong, 2014, p. 8). Aceste argumente dovedesc, mai degrabă, că este dificil să stabilim care este acea trăsătură unică care definește natura umană.

Subiectivitatea în ceea ce privește definiția inteligenței se observă și din analiza teoriilor care pun accentul pe ceea ce face o i.a. O definiție a ce este inteligența sau o acțiune care este o dovadă a inteligenței, s-a schimbat de-a lungul anilor și a fost comparată cu diferite invenții sau dezvoltări 
tehnologice. Inteligența umană a fost comparată, pe rând, cu un calculator, cu un cu un mecanism de ceas, cu o mașinărie și în prezent cu un computer. Această dificultate de definiție s-a reflectat și în analiza i.a. De la apariția acestei tehnologii, după cum observă Nick Bostrom și Eliezer Yudkowsky, ori de câte ori o i.a. a reușit să depășească omul într-o activitate, precum Deep Blue în cazul șahului, acea abilitate a i.a. încetează să mai fie considerată o trăsătură a inteligenței (Bostrom \& Yudkowsky, 2014).

Această reclasificare reprezintă un tipar istoric care se repetă până în prezent, spune Stuart Armstrong și a început atunci când primele calculatoare au început să fie capabile de calcule matematice complexe, deci când aceste abilități au început să fie realizate mai eficient de către calculatoare (Armstrong, 2014). Cu toate acestea, nu putem vorbi de o stagnare a capacităților i.a. pentru că fiecare domeniu în care au excelat de-a lungul timpului reprezintă un progres și o dezvoltarea graduală a acestei tehnologii.

O trăsătură comună a i.a. din prezent este absența generalității. Mai concret, chiar și cele mai avansate i.a. sunt programate pentru un singur scop. Revenind la exemplul lui Deep Blue, acesta este un excelent jucător de șah, dar nu este capabil de alte activităţi. Aceste sisteme sunt asemănătoare regnului animal și vegetal, spun Hirschfeld Lawrence şi Susan Gelman. Potrivit lor, specializarea i.a. într-un singur domeniu poate fi comparată cu specializarea unei albine în a crea un stup sau capacitatea unei păsări de a construi un cuib. Fiecare din vietățile din cele două exemple este expertă în ceea ce face, dar fiecare este limitată la domeniul ei fără să poată ieși din această limitare. Omul poate învăţa mai multe abilități prin observare și învățare. Nu se știe exact cât de generală este inteligența umană, dar este cu siguranță aplicabilă într-un mod general (Hirschfeld, \& Gelman, 1994). Pentru a putea opera cu un sistem moral, i.a. trebuie să aibă o inteligență generală pentru că situațiile pot varia de la context la context; iar scopul acestor teorii este de a putea găsi o soluție etică pentru cât mai multe scenarii posibile.

Pe lângă generalitate, este necesară și o anumită măsură de conștiență și flexibilitate. De exemplu, atunci când un inginer proiectează un echipament, el are în minte un scop și un design specific pentru acel echipament. Echipamentul în sine nu este conștient, atfel încât el nu știe ce scop are și astfel pot apărea efecte neprevăzute atunci când echipamentul este folosit în afara scopului stabilit de creatorul său. La fel este situaţia cu i.a. în prezent. După cum punctează Nick Bostrom și Eliezer Yudkowsky, acestea sunt programate să operaționeze în anumiți parametrii, dar nu pot mai mult de atât. Orice comportament care este programat va fi de nivelul programatorilor și 
fiind un sistem fixat, nu va putea trece dincolo de nivelul acesta (Bostrom \& Yudkowsky, 2014)

În cazul unei i.a, ajunsă la un nivel uman sau devenită autonomă, ea este obligată să-și aplice rațiunea eficient și corespunzător la un context existent, deci să fie destul de flexibilă încât să-și poată observa și realiza scopul ei. Iar, metoda implementării unor contexte anterioare este imposibilă pentru că pot exista o infinitate de contexte posibile și este imposibilă programarea tuturor acestora. Situația cea mai realistă este ca i.a. să ajungă la o soluție prin deducție sau inducție.

Această generalitate, împreună cu flexibilitatea în procesarea datelor, le-ar permite i.a. să-și depășească slăbiciunile într-un mod asemănător omului. Natura nu a înzestrat omul din naștere cu un set infinit de abilități, ci 1-a înzestrat cu adaptabilitate. Iar prin această adaptabilitate generală a inteligenței umane, omul a putut ajunge la nivelul la care se află în prezent. În cazul i.a. i-ar permite să operaționeze într-o multitudine de contexte care trec dincolo de baza de la care a început, chiar și în contexte în care creatorii ei sau chiar oamenii în general nu știu cum să acționeze. Având acest avantaj, i.a. ar putea găsi, de asemenea, soluții morale la care oamenii nu s-au gândit până în prezent.

Tot legat de rațiune, trebuie să ne punem întrebarea: Poate o i.a. să-și creeze o cultură sau poate avea una? Cultura este o trăsătură definitorie pentru natura umană. Termenul cultură cuprinde comportamente, norme, valori ale unei societăţi umane, dar cuprinde, la un nivel individual, cunoștiințe, credințe, arte, legi, obiceiuri și tradiții (Macionis \& Gerber, 2011). În cazul omului, cultura este creată prin învățare, culturalizare și socializare.

La nivelul prezent, i.a. cea mai des folosită este cea de tip slab. Acele inteligențe artificiale care sunt create să servească un singur scop, de la telefonul mobil la asistenții virtuali, prin capacitățiile lor nu pot să-și creeze propria cultură. Ele nu-și aleg scopul, creatorii lor îi creează pentru un singur scop. Astfel, acestea pot fi văzute asemeni unor oameni îngrădiți într-un anumit spațiu, făcând un singur lucru și având acces doar la strictul necesar pentru a realiza acel scop definit și nu ales. Aceștia nu vor putea crea niciodată o cultură, ci putem spune că aceștia sunt o anexă sau o extensie a culturii din care fac parte creatorii lor. De exemplu i.a. utilizate în rețelele de socializare nu vor crea nimic nou, vor continua să dezvolte un design al creatorilor umani care, la rândul lor, se folosesc de cultura lor pentru a crea i.a. În concluzie o i.a. de tip weak este ea însăși un obiect cultural și nu un vector de culturalizare.

Putem spune că o posibilă cultură creată de o inteligență artificială este echivalentă cu nivelul ei de inteligență. Un sistem etic/moral face parte dintr- 
o cultură, astfel dacă o inteligență artificială ajunge la un nivel de inteligență generală care să-i permită să lucreze cu un sistem etic aplicat natural și nu doar prin simulare, atunci ea este în stare și să înțeleagă conceptul de cultură. Mai ales pentru că moralitatea nu este fixă, ea diferă de la o cultură la alta şi această flexibilitate în a opera cu idei abstracte i-ar permite unei inteligențe artificiale să poată opera și cu idei legate de cultură.

Dar, pentru a putea creea o cultură proprie, o inteligență artificială necesită ceea ce se numește o super inteligență. În momentul de faţă suntem foarte departe de a avea o astfel de tehnologie. Fără a intra în domeniul science fiction, o super inteligență la nivel i.a. ar presupune o inteligență care, fiind o imitație a inteligenței umane, nu ar fi o simplă extensie a acesteia (Bostrom, 2014, p. 50). Ci ar folosi inteligența umană ca o bază sau ca un punct de start pentru a-și crea ea următoarele etape. Ar imita mecanismul uman al progresului. $\mathrm{Cu}$ fiecare nouă generație, umanitatea înregistrează un progres față de generația anterioară, cel puțin în ceea ce privește satisfacerea nevoilor. O inteligență artificială înzestrată cu capacitatea de a-și crea propria cultură ar duce la noi structuri comportamentale, posibil chiar la tradiții și religii. Ajunsă la un nivel atât de mare de complexitate, o i.a. ar fi în stare să dezvolte, asemeni omului, idei abstacte. Dar, din nou, nu este vorba doar despre o simplă imitație sau o extensie, ci o creație proprie adaptată nevoilor ei și nu nevoilor omului. De exemplu, dacă are un corp sintetic, o i.a. ar putea elimina slăbiciunile umane și ar deveni o ființă proprie, cu o cogniție proprie, pornind de la diferențele față de structura umană.

\subsection{Trupul}

În cazul i.a, importanța trupului, din nou, depinde de tipul acestuia. În cazul i.a. de tip weak a.i, trupul este echipamentul unde funcționează i.a. De exemplu, telefonul mobil cuprinde hardware necesar atât să funcționeze cât și să permită unui tip de i.a. să funcționeze, respectiv spațiu de stocare și procesor pentru a putea funcționa toate optim. La fel este și în cazul rețelelor de neuroni artificiali și a funcțiilor de Machine Learning și Deep learning . În toate cazurile de mai sus, există două trăsături comune: i.a. nu este conștientă de trupul ei și într-o anumită măsură poate avea două trupuri, respectiv piesele care îi asigură funcționalitatea și apoi echipamentul pentru care ele sunt utilizate.

Dar, cu cât i.a. este mai complexă, cu atât poate avea o altă perspectivă asupra relației cu trupul. Pentru unii experți precum Ronald Arkin, lipsa durerii, a grijii pentru trup reprezintă un avantaj pentru i.a. Ele pot funcționa mai eficient și își pot îndeplini scopurile mult mai bine fără acest impediment. 
(Arkin, 2009, p. 32) Dar oare este aceasta un avantaj real? Acest avantaj începe să dispară când este vorba de o i.a. generală sau care funcționează asemeni unui om. Mai ales când este vorba de moralitate, percepția și înțelegerea durerii și a suferinței joacă un rol important. Pentru om, moralitatea are la bază o viață în care durerea apare constant, ceea ce a dus la o înțelegere a ei și la dezvoltarea empatiei, care reprezintă una din bazele moralității.

O dată cu evoluția i.a. ne putem pune întrebarea: Dacă inteligența artificială ajunge la un nivel uman, va fi necesar pentru ea să aibă și un trup pentru a ajunge la un nivel uman? Deoarece suntem încă departe de a crea o inteligență artificială care să aibă o conștiință similară omului, dincolo de mimă și cu capacitatea de a se conștientiza ca o persoană, putem doar aproxima ce comportament ar avea dacă ar înțelege ce înseamnă să aibă sau să nu aibă un trup și slăbiciunile legate de el.

Unii experți precum Hubert Dreyfus susțin că lipsa trupului reprezintă, mai degrabă, o știrbire a inteligenței. Deși o i.a. poate fi complexă și avansată, fără un trup, ea poate întâmpina multiple situații unde este mai puțină nevoie de un sistem cognitiv puternic și este mai multă nevoie de o intervenție practică, ceea ce se poate realiza doar printr-un trup (Dreyfus, 1972).

Mai exact, atunci când învățăm ceva nou, precum condusul, dansatul sau o nouă limbă, întâi învățăm regulile acelei activități, gen mișcările de dans sau manevrele de condus. După care, experiența, dobândită prin aceste reguli, este transferată trupului. Și nu este doar o simplă transpunere, ci experiența este însuşită și este reprodusă într-un mod flexibil și eficient. Asta se aplică și obiectelor, doar prin atingere putem simţi textura unui obiect sau forma. După cum spune Piaget, constanța perceptuală este realizată cu ajutorul organelor din trup. Avantajul care există faţă de i.a. este că trupul uman este flexibil și poate identifica un obiect pe care îl cunoaște, chiar dacă obiectul este într-un context nou. Un calculator ar trebui să aibă în baza de date proprie toate datele legate de obiect și să le compare cu input-ul pe care îl primește din exterior pentru a vedea cu care trăsături, din baza lui de date, se potrivește obiectul, iar asta poate duce la erori (Piaget, 1966).

\subsection{Comunicarea}

Ultima parte necesară pentru ca i.a. să fie atât umană cât și capabilă de moralitate este comunicarea şi sociabilitatea. În primul rând, putem să punem întrebarea dacă i.a. comunică. Pe scurt, da comunică, dar la o analiză mai amănunțită, întrebarea pe care ar trebui să o punem este dacă comunicarea pe 
care aceste sisteme o realizează este comunicare în înțelesul dat de oameni, sau dacă este vorba de o simulare a comunicării.

Comunicarea este importantă pentru că doar prin comunicare o i.a. poate interacționa într-un mod uman și doar prin comunicare ea poate fi capabilă să înțeleagă sensul și valoarea unui lucru, fapt sau persoană. Întrebarea ar fi atunci: Cum pot oamenii și i.a. comunica într-o manieră în care dialogul are sens, valoare și un rol constructiv în relaţia celor doi? Cuvântul "comunicare" provine de la cuvântul latin "communis (is)" și înseamnă "comun". Într-o comunicare la care participă doi agenți, unul încearcă să transmită celuilalt interpretarea unei experiente sau a unui element abstract. Astfel, fără socializare, limba își pierde sensul. În cazul omului, este un proces interpretativ comun, care trece dincolo de comunicare. Este vorba de crearea de sens în mediul său, natural sau social.

Însă, un schimb de interpretări, între om și i.a., este dificil în prezent. Omul poate învăța cum funcționează interfața unui software, cum să folosească comenzi digitale sau limbajul de programare pentru a putea manipula un sistem computațional. La rândul lor, sistemele de i.a. pot folosi limbaj uman sau matematic pentru scris, tradus. Dar, pentru a putea realiza o comunicare semnificativă, este nevoie ca interpretările realizate de i.a. să influențeze programarea lor din punct de vedere habitual și programatic.

Soluția este ca procesul de comunicare să se realizeze pe baza interpretării. În acest caz, este de ajutor semiotica. Potrivit acesteia, organismele pot realiza interpretări ale lumii prin înțelegerea și utilizarea simbolurilor/semnelor. Conform lui Mark Graves (2017), teoriile lui Charles Pierce despre relația între un obiect și simbolul lui se pot aplica și în cazul i.a. Această relație poate avea trei forme. Iconul/ semnul iconic reprezintă simbolizarea prin asemănare, precum o hartă sau un tablou. În esență are o trăsătură care seamănă sau copiază o trăsătură a obiectului. Apoi, indexul/indicele reprezintă obiectul printr-o legătură existențială între sine și obiect, de ex: amprenta reprezintă atât forma unei amprente dar este și o reprezentare particulară a unui deget. În final, simbolul reprezintă obiectul printr-o convenție care dictează felul în care simbolul este utilizat. Un simbol este legat printr-o convenție, fără să existe vreo asemănare directă, existențială sau cauzală între simbol și obiect. În cazul i.a, acestea au fost concepute să recunoască simbolurile, dar din cauză că inițial nu aveau o putere amplă de procesare, simbolul nu este perceput în același mod precum în lumea naturală. Și-au pierdut dimensiunea socială, metaforică, au fost implementate mecanic și au rămas la nivelul de icon sau index. Semiotic, simbolul este o unitate de semnificație care reprezintă un obiect ca un obicei convențional de 
interpretare. Această legătură habituală se referă la o dispoziție generală. Orice colectiv care este capabil să formeze convenții de interpretare poate crea simboluri. Astfel, în viitor, când oamenii și i.a. vor putea să-și dezvolte capacități interpretative comune pentru a putea interpreta împreună simbolurile din viața de zi cu zi, atunci putem vorbi de comunicare semnificativă (Graves, 2017).

O altă trăsătură semnificativă pentru comunicare este abilitatea de a putea recunoaște sau înțelege ce spune celălalt. Modul în care i.a. identifică structura unui limbaj se realizează prin analiza părților rostite pe care le compară cu un tipar memorat. După care, fiecare sunet este asignat unui bloc de interpretare. Dar, când e vorba de mai mult cuvinte, acestea pot depăşi blocurile de interpretare, devenind astfel ineficiente. Oettinger susține că percepția unui cuvânt este o consecință a percepției și nu parte din ea. Mai concret, în analiza unei propoziții, sensul ei ca întreg determină valoarea asignată părților ei constituente. Într-o conversație, sensul unei propoziții este singular și numai după ce este percepută ca o singularitate, poate ea să fie despărțită în părțile ei constituente. (Oettinger, 1968. p. 297)

\section{Concluzii}

În concluzie, pentru ca o i.a. să poată beneficia de un sistem moral este necesar ca să aibă anumite componente și trăsături: o inteligență generală flexibilă și adaptabilă pentru a-și putea stabili scopul acțiunilor sale, o formă semnificativă de percepție a suferinței pentru a putea empatiza. Și în final, să poată comunica într-un mod natural, să poată crea semnificații și interpretări care să-i poată influența comportamentul.

\section{Referințe}

Aristotel. (1959). Politics. Londra: Harward University Press.

Aristotel. (2002). The Nicomachean Ethics. Minnesota: Focus Publishing.

Aristotel. (2006). Poetics. Minnesota: Focus Publishing.

Arkin, R. (2009). Ethical Robots in Warfare. IEEE Technology and Society Magazine, 28, 30-33.

Armstrong, S. (2014). Smarter than us: The Rise of Machine Intellgence. Cambridge: Cambridge University Press.

Bostrom, N. (2014). Superintelligence. Paths, Dangers, Strategies. Oxford: Oxford University Press. 
Bostrom, N., \& Yudkowsky, E. (2014). The Ethics of Artificial Intelligence. In K. Frankish, \& W. M. Ramsey (Eds.), The Cambridge Handbook of Artificial Intelligence (pp. 316-335). Cambridge: Cambridge University Press.

Clarke, D. (2007). Blaise Pascal. Retrieved from: https://plato.stanford.edu/entries/pascal/.

D’Aquino, T. (1997). Summa Theologiae Despre Dumnezeu. București: Editura Științifică.

D’Aquino, T. (2014). Summa Theologiae. London: Catholic Way Publishing.

Descartes, R. (2017). Meditations on the First Philosophy. Cambridge: Cambridge University Press.

Dicker, G. (2013). Descartes: An Analytic and Historical Introduction. Oxford: Oxford University Press.

Dreyfus, H. (1972). What Computers can't do. New York: Harper \& Row.

Flynn, T. (2004). Jean-Paul Sartre. Retrieved from: https://plato.stanford.edu/entries/sartre/.

Friedman, M. (2004). Ernst Cassirer. Retrieved from: https://plato.stanford.edu/entries/cassirer/.

Graves, M. (2017). Shared Moral and Spiritual Development Among Human Persons and Artificially Intelligent Agents. In Theology and Science, 3(15), 333-351.

Hirschfeld, L., \& Gelman, S. (1994). Toward a topography of mind: An introduction to domain specificity. In L. Hirschfeld, \& S. Gelman (Eds.), Mapping the mind Domain specificity in cognition and culture (pp. 3-37). Cambridge: Cambridge University Press.

Hobbes, T. (1998). Leviathan, Oxford: Oxford University Press.

Locke, J. (1996). An Essay Concerning Human Understanding. Indianopolis: Hackett Publishing Company.

Macionis J., \& Gerber L. M. (2011). Sociology. Toronto: Pearson Prentice Hall.

McLaughlin, T. \& Lentricchia, F. (1990). Critical Terms for Literary Study. Chicago: The University of Chicago Press

Oettinger, A. (1968). Language and Information. In American Documentation, 19(3), 295-298.

Pascal, B. (2013). Pensees. Londra: Penguin Books.

Piaget, J. (1966). Psychology of Intelligence. New York: Humanities Press.

Platon. (1976). Alcibiade. În F. Băltăceanu, M. Guțu, S. Vieru, S. Noica, D Slușanschi, A. Cizek, \& Ș. Mironescu (Trad.), Opere, Vol. 1 (pp. 83155). București: Științifică și Enciclopedică. 
Platon. (1986). Republica. În A. Cornea (Trad.), Opere, Vol. 5 (pp. 81-445). București: Științifică și Enciclopedică.

Platon. (2013). Theaetetus. București: Humanitas.

Rousseau, J. J. (1968). The Social Contract. Indianopolis: Hackett Publishing Company.

Rousseau, J. J. (2012). Discourse on the origin and foundations of inequality among men. In D.A. Cress (Ed.), Rousseau: The Basic Political Writings $2^{\text {nd }}$ Ed. (pp. 27-93). Cambridge: Hackett Publishing Company.

Russe, S., \& Norvig, P. (2009). Artificial Intelligence: A Modern Approach. New Jersey: Prentice Hall.

Sartre, J. P. (1978). Being and Nothingness. New York: Pocket books.

Sf. Augustin. (2010). On the free choice of the Will. In P. King. (Ed.), Augustine: On the Free Choice of the Will, On Grace and Free Choice, and Other Writings (pp. 3-127). Cambridge: Cambridge University Press.

Turing, A. (1950). Computing Machinery and Intelligence. Mind, 59(236), 433-460.

Vlastos, G. (1983). The Socratic Elenchus. În J. Annas (Ed.), Oxford Studies in Ancient Philosophy, Vol. 1 (pp. 27-58). Oxford: Oxford University Press.

Wraight, C. (2008). Rousseau's The Social Contract: A Reader's Guide. Londra: Continuum Books. 